\title{
First occurrence of the orectolobiform shark Akaimia in the Oxford Clay Formation (Jurassic, Callovian) of England
}

\author{
Alex Srdic $*^{\mathrm{a}}$, Christopher J. Duffin ${ }^{\mathrm{b}, \mathrm{c}}$, David M. Martill ${ }^{\mathrm{a}}$ \\ ${ }^{a}$ School of Earth and Environmental Sciences, University of Portsmouth, Portsmouth, POI \\ $3 Q L$ \\ ${ }^{b}$ Palaeontology Section, Earth Science Department, The Natural History Museum, Cromwell \\ Road, London, SW7 5BD, UK. \\ ${ }^{c}$ 146, Church Hill Road, Sutton, Surrey SM3 8NF
}

\begin{abstract}
The late Middle Jurassic (Callovian) Peterborough Member of the Oxford Clay Formation of eastern England yields a rich variety of marine vertebrate fossils, including a diverse assemblage of neoselachian elasmobranchs. Here we report the first record of the small Jurassic orectolobiform shark Akaimia Rees, 2010, otherwise known only from Poland and Germany, from the British Jurassic, together with an unusual, undetermined dermal denticle. The material comes from exposures in Cambridgeshire, eastern England. We refer the new specimens of Akaimia to the new taxon A. myriacuspis sp. nov., and provide a revised diagnosis for the genus.
\end{abstract}

Keywords: Jurassic, Callovian, Microvertebrates, Neoselachii, Orectolobiformes, England 


\section{Introduction}

The Callovian Oxford Clay Formation of England, best regarded for its vertebrate fauna of large marine reptiles and diverse and sometimes gigantic bony fishes (Woodward, 1890; Andrews, 1910-13; Brown, 1981; Martill, 1991; Liston, 2008), has also produced a diverse assemblage of elasmobranchs since sampling began in the mid- $19^{\text {th }}$ century (Woodward, 1889; Thies, 1983; Martill and Hudson, 1991). At least 25 elasmobranch species have been described to date (Thies, 1983; Rees and Underwood, 2008). These taxa range from large active predators such as Hybodus and Asteracanthus (Hybodontidae) to likely benthic animals such as Synechodus (Palaeospinacidae), the Angel shark Pseudorhina (Pseudorhinidae) (Carvalho et al., 2008; Klug and Kriwet, 2013) and a Guitar fish, Spathobatis (Rhinobatidae) (Thies, 1983). The latter two taxa represent groups which are still extant in oceans today, appearing to differ little from their Jurassic relatives (Thies and Leidner, 2011). Similar elasmobranch assemblages to those of the Oxford Clay Formation have been reported from the Callovian and Oxfordian of Poland and Germany (Thies, 1983, 1989; Kriwet and Klug, 2004; Rees, 2010). Here we describe the first record of the genus Akaimia (Rees, 2010) outside of mainland Europe, a genus unrelated to, but with traits similar to the extant Wobbegongs or Carpet sharks (Orectolobidae) of the Indo-Pacific region (Rees, 2010).

\section{Geological setting}

The Middle Jurassic Oxford Clay Formation is a sequence of organic-rich clays and shales deposited in a shallow epeiric sea during the Callovian, a time when much of Europe was submerged due to a global rise in sea level (Hudson and Martill 1994, Hallam 2001) with water column temperatures in the $11^{\circ} \mathrm{C}$ to $17^{\circ} \mathrm{C}$ range (Mettam et al., 2014). The basal Peterborough Member crops out extensively to the East of Peterborough where since the late$18^{\text {th }}$ century it has been dug commercially for brick manufacture. Today only Must Farm pit 
at Kings Dyke, Whittlesey, Cambridgeshire (National Grid reference TL237974) remains operational, although it still yields a plethora of fossils (Fig. 1).

\section{FIGURE 1 HERE}

Historically this clay pit is one of several very important sites around the Fenland Town and Whittlesey area for Oxford Clay fossils (Benton and Spencer 1995). Commercial excavation of the Oxford Clay began in the late 1800's resulting in the discovery of hundreds if not thousands of vertebrate skeletons, many collected by Alfred Nicholson Leeds (18471917) and his elder brother Charles (born 1845) of Eyebury and Henry Keeping (1827-1924) at Cambridge University between c. 1867 and 1917 (Leeds, 1956; Araujo et al., 2008).

The Oxford Clay Formation sequence exposed at Whittlesey is incomplete. The lower boundary of the Oxford Clay Formation is sometimes exposed in the pit bases, with the underlying Kellaways Formation revealed in drainage ditches (Martill and Hudson 1991)

(Fig. 2). The main quarry face usually exposes the entire sequence of the Peterborough Member, and the overburden may consist of weathered parts of the Stewartby Member. However, the Stewartby Member is sometimes absent and replaced with Holocene Fen gravels and peat deposits. The Peterborough Member spans the upper part of the Lower Callovian and extends upwards into the base of the Upper Callovian (Hudson and Martill, 1991).

\section{FIGURE 2 HERE}

\subsection{Taphonomy}

The teeth found in the Oxford Clay are well preserved, with little etching or abrasion noted. Many teeth are missing cusps or roots, although these breakages may have occurred post- fossilisation during collection and mechanical processing. Networks of micro-borings (Underwood et al., 1999) belonging to the ichnotaxon Mycelites ossifragus (Roux, 1887) are 
noted on the lingual face of the indeterminate denticle and roots of many of the Akaimia teeth (see section 5) as well as other teeth found during the taphonomic study.

\section{Late Jurassic neoselachian sharks}

Neoselachians embrace those groups of living sharks and rays which are represented in modern seas, as well as their fossil relatives and some extinct families. As with all fossil chondrichthyans, they are mostly represented by isolated teeth in the fossil record because the high protein content of the cartilaginous skeleton is easily lost during decomposition, thereby reducing the preservation potential of the elements of the endoskeleton. The dental character that unites neoselachians is the presence of a triple-layered enameloid covering the surface of the crown.

Neoselachians seem to have had their origins in the Palaeozoic (Ginter et al., 2010), but do not become diverse until the Mesozoic (Cappetta, 2012). Many of the late Triassic forms are difficult to place with any certainty into higher taxonomic categories, other than identifying them as neoselachians, and it is only in the Jurassic that members of extant orders can be identified with any degree of confidence. A particularly important resource in this respect is the occurrence of several conservation Lagerstätten in the Jurassic of Europe; articulated whole-bodied chondrichthyan specimens are known, for example, from the Sinemurian of Lyme Regis (Dorset, UK) and Osteno in Italy, the Toarcian of Holzmaden in Germany, and the Kimmeridgian of Kimmeridge (Dorset, UK), plus the Tithonian lithographic limestones of Nusplingen and Solnhofen in southern Germany, and Cerin in eastern France. These spectacular deposits with their perfectly preserved faunas clearly indicate that the range of modern chondrichthyan body forms was fully established in or by Jurassic times. Our understanding of the intervening record of neoselachian orders necessarily depends on finds of isolated teeth. Since many of these are in the sub-millimetric size range, it is necessary to 
concentrate and isolate them from enclosing sediments using a variety of mechanical and chemical techniques. The Jurassic represents a particularly interesting time in the evolution of the Neoselachii, but the bulk sampling necessary to elucidate the development of a true picture of changing chondrichthyan faunal diversity throughout the Period is only in its early stages.

\section{Methods}

Samples for microvertebrate processing were taken from beds 6, 7, 11, 13, 17 and 19 (Bed numbers from Hudson and Martill 1994) as part of a taphonomic study examining the relative abundances of otoliths and phosphatic skeletal fish remains. At least $2 \mathrm{~kg}$ of clay was collected from each bed, and air dried prior to disaggregation in $10 \%$ hydrogen peroxide. The resultant residues were sieved between $250 \mu \mathrm{m}$ and $4 \mathrm{~mm}$ sieves to remove silt and clay, while coarser shelly material was removed manually. Microvertebrate remains were picked under a binocular microscope and mounted on aluminium SEM stubs for examination by JEOL JSM-6100 scanning electron microscope at 10kv. Images were digitally processed. The material described here has been accessioned into the collection of the Natural History Museum, London numbers NHMUK PV P 73690 - P 73695.

\section{Systematic palaeontology}

The descriptive tooth terminology used here follows Cappetta (2012), which is also the source for the higher taxonomic relationships of the Neoselachii. A key to the descriptive terms used in the text is given for the sake of convenience in Fig. 3.

\section{FIGURE 3 HERE}

\subsection{Euselachii indet.}

Subclass ELASMOBRANCHII Bonaparte, 1838 


\section{Cohort ?EUSELACHII Hay, 1902}

Euselachii indet.

Material - One near complete undetermined dermal denticle or possible oropharyngeal denticle, NHMUK PV P 73695 (Fig. 4).

Locality - Bed 17 of the Peterborough Member of the Oxford Clay Formation at Must Farm Pit, Whittlesey, United Kingdom. GR TL237974.

Description - The asymmetrical denticle features a single large 'cusp' and four lateral 'cusplets' (one $v$ three either side of the main cusp). Each cusp bears acute lateral margins and is curved labio-lingually. The lingual surface shows numerous borings of the possible fungus Mycelites ossifragus (Roux, 1887).

Remarks - This dermal denticle is described here because of its somewhat unusual morphology and very small size. It is regarded as elasmobranchian on account of the morphology of the crown with major cusp and lateral cusplets and the texture of the basal body (root). Furthermore, chimaeroids, frequently represented by isolated tooth plates in the Oxford Clay Formation, lack denticles in the skin, apart from some specialised structures in the dorsal midline of the body. The denticle is identified as euselachian on somewhat negative grounds. Hybodontoids tend to have dermal denticles that are simple dome-like bodies with strongly buttressing ribs, quite unlike those of neoselachians (see figures in e.g. Brito and Ferriera 1989, Martill 1991). Although we regard this specimen to be of probable euselachian origin, its identification both as a euselachian and as a dermal denticle are tenuous. There is a superficial similarity of the form with oropharyngeal denticles seen in such widely divergent gnathostomes as hybodont sharks and placoderms (Johanson and Smith 2003), being strongly labio-lingually curved with a 'ctenoid' cusp arrangement.

\section{FIGURE 4 HERE}

\subsection{Akaimia}

Subcohort NEOSELACHII Compagno, 1977 
Order ORECTOLOBIFORMES Applegate, 1972

Family indet.

Genus AKAIMIA Rees, 2010

Type Species - Akaimia altucuspis Rees, 2010 from the uppermost Callovian to lowermost Oxfordian of Southern Poland.

Revised diagnosis - A revised diagnosis for Akaimia includes the following characters 1: A high degree of monognathic heterodonty; 2: anterior teeth with a high and slender central cusp; 3: at least one pair of short lateral cusplets in anterior teeth; 4: lateral teeth considerably lower with a flattened, triangular cusp; 5: a single, strong, and centrally placed labial keel on the lower part of the tooth; 6: hemiaulacorhize root vascularisation.

\subsection{Akaimia myriacuspis $s p . n o v$.}

Holotype - NHMUK PV P 73690 (Figs 5a-e), a complete anterior tooth.

Paratypes - NHMUK PV P 73691 (Figs 5f-h), mostly complete anterior tooth, missing one of the first pair of cusplets; NHMUK PV P 73692 (Figs 5i-k), a damaged tooth missing some of the lateral cusplets; NHMUK PV P 73693 (Figs 51-o), a lateral tooth with worn cusplets).

Additional material - One additional damaged tooth (NHMUK PV P 73694, Figs 5p,q) is tentatively referred to A. myriacuspis here, based on the presence of additional carinae below the outermost cusplets despite appearing to lack the central ridge.

Derivation of name - The specific name myriacuspis derives from myriad (Greek, murios $=$ ten thousand, indicating 'many') and cuspis (Latin = point) alluding to the many cusps.

Type Stratum - Bed 17 (see Hudson and Martill, 1994) of the Peterborough Member of the Oxford Clay Formation.

Type locality - Must Farm Pit, Whittlesey, Cambridgeshire, United Kingdom. National Grid reference TL237974. 
Differential diagnosis - Akaimia myriacuspis sp. nov. is differentiated from the type species

A. altucuspis by the possession of up to three pairs of lateral cusplets whose long axes are sub-parallel to that of the central cusp, a weaker labial apron, a stronger lingual uvula in lateral teeth, and the form of the vertical ridge ornamenting the labial face of the crown.

Diagnosis - Orectolobiform shark known from three complete anterior teeth and one lateral tooth. Characterised using the generic diagnosis revised above with the following additions for species level identification; 1: at least two pairs of short but well-developed lateral cusplets; 2: lateral cusplet axes sub-parallel to that of the central cusp in anterior teeth; 3: a well-developed lingual apron on the lateral tooth only; 4: ornamental ridges smaller than the central keel on the labial surface below the cusplets.

Description - The holotype (NHMUK PV P 73690; Figs 5a-e) is an anterior tooth which measures $1 \mathrm{~mm}$ mesiodistally from tip to tip of the mesial and distal lobes of the root, and $1.67 \mathrm{~mm}$ from the labial margin of the labial apron to the central cusp apex on the crown. The tooth is slightly asymmetrical (Fig. 5b); the tall, relatively slender, sharply-pointed central cusp is angled slightly distally. It is flanked by two pairs of lateral cusplets, the heights of which decrease away from the central cusp (Figs 5a-b). The first lateral cusplet pair is around $40 \%$ of the height of the central cusp, while the second lateral cusplet pair is only around $17 \%$ of the central cusp height. Both lateral cusplet pairs are sharply pointed, and all of the cusps possess sharp cutting edges which descend the lateral margins of the cusp mesially and distally. The lateral cusplets are sub-parallel to central cusp, their axes diverging from that of the central cusp by only a few degrees. In cross-section, the cusps are slightly flattened labio-lingually. A moderate labial apron is developed on the crown margin beneath the central cusp base, and significantly overhangs the root (Figs 5d, e). Coronal ornamentation is restricted to the labial face of the crown. A prominent, short vertical ridge is developed above the labial apron at the level of the central cusp base (Figs 5b, e). A short uvula is developed lingually. The root has a V-shaped basal surface and a prominent lingual foramen is present on the baso-lingual margin beneath the central cusp. Lateral foramina are present midway up the root wall mesially and distally. The mesial and distal lobes of the root extend slightly beyond the mesial and distal heels of the crown. 
Further anterior teeth in the collection (NHMUK PV P 73691, NHMUK PV P 73692) show less

prominent labial aprons with much straighter labial margins and less significant overhang of the neck or collar and the root (Figs 5g, h, I, k, p, q). The base of the central cusp may be somewhat inflated mesiodistally (Figs 5f, i) and an incipient third pair of lateral cusplets may be developed (NHMUK PV P 73692; Fig. 5i). The uvula is consistently weak in anterior teeth, but the available specimens show some variation in labial ornamentation. The labial vertical ridge may be less prominent than is the case in the holotype (Figs 5g-h, p-q), or it may be significantly stronger (Figs 5i-j). Short lengths of vertical ridge may also be developed below the bases of the lateral cusplets (Figs 5i-k, p-q).

\section{FIGURE 5 HERE}

A single lateral tooth, slightly wider $(1 \mathrm{~mm})$ than it is high, is present in the sample. This has a much squatter, triangular, shorter central cusp which is a little more upright than in anterior teeth. The mesial and distal cutting edges are consistently and strongly developed. The central cusp is flanked by two pairs of lateral cusplets which are much shorter and possess a less acuminate, more rounded outline than is the case in the holotype. The labial apron is prominent and the lingual uvula very strongly developed. The labial vertical ridge is rather longer than in anterior teeth, extending from the base of the central cusp almost half way to the cusp apex. There are no vertical ridges basal to the lateral cusplets. The root is slightly deeper than in anterior teeth, and the flared mesial and distal lobes extend well beyond the mesial and distal heels of the crown.

Heterodonty - There is clearly a high degree of heterodonty between the anterior and lateral teeth of A. myriacuspis. Changes taking place distally through the dentition include a change in proportions from anterior teeth which are one and a half to two times higher than wide to lateral teeth in which the height and width are approximately identical. A long, slender central cusp flanked by up to three pairs of lateral cusplets with their long axes sub-parallel to that of the main cusp in anteriors gives way to a more squat, triangular central cusp flanked by relatively shorter, more rounded lateral cusplets in laterals. The ornamentations also shows some changes with heterodonty; short but sometimes very well developed in anterior teeth, the vertical ridge at the base of the central cusp becomes longer in lateral teeth. Short vertical ridges beneath the lateral cusplet bases seems to be confined to some 
anterior teeth. The rather weak uvula in anterior teeth is replaced by a strong and relatively high one bulbous and prominent in lateral teeth.

Remarks - The teeth of Akaimia myriacuspis and A. altucuspis are similar but clearly belong to two separate species. The most obvious difference is the presence of additional pairs of lateral cusplets in A. myriacuspis; teeth of A. altucuspis possess a single pair of lateral cusplets in both anterior and lateral teeth, while up to three pairs are present in A myriacuspis. Furthermore, the long axes of the lateral cusplets are sub-parallel to the central cusp in A. myriacuspis, but diverge strongly from the central cusp axis in A. altucuspis (Rees, 2010 pl. 1 figs 4, 15, 16). The central cusp itself is more elongate and gracile in A. altucuspis, and lacks the somewhat inflated base found in some anterior teeth of $A$. myriacuspis. In lateral view, the central cusp may have a sigmoid flexure in some specimens of $A$. altucuspis (Rees, 2010 pl. 1 figs 2, 7), a feature lacking in A. myriacuspis. The labial apron in anterior teeth of $A$. myriacuspis is much reduced when compared to the condition in $A$. altucuspis; the labial margin of the apron is almost straight in some specimens of $A$. myriacuspis (NHMUK PV P 73691 and P 73692 Figs 5f-k), whilst it is prominent and very well developed with parallel lateral margins in some specimens of A. altucuspis (Rees, 2010 pl. 1 figs 6, 7, 9). The lingual uvula in lateral teeth of $A$. myriacuspis is much more strongly developed compared to that in $A$. altucuspis.

In terms of crown ornamentation, both $A$. myriacuspis and A. altucuspis display a vertical ridge in the centre of the labial face of the crown, toward the base of the central cusp. In A. altucuspis, the ridge is longer in anterior teeth, extending from part way up the central cusp to a point very close to the labial margin of the labial apron. The teeth of $A$. myriacuspis are distinctive in that, although relatively short, the vertical ridge is very strongly developed in some specimens (Figs 5 i-k). Furthermore, the presence of short lengths of vertical ridge beneath the bases of the lateral cusplets in anterior teeth is a feature confined to some specimens of A. myriacuspis. 


\section{Discussion}

There are a number of additional orectolobiform genera represented in Jurassic rocks, namely Heterophorcynus (Bathonian of England), Dorsetoscyllium (Bathonian of England), Folipistrix (Toarcian to Aalenian of Belgium and Germany), Phorcynis (Kimmeridgian to Tithonian of Europe), Palaeobrachaelurus (Aalenian to Barremian), Annea (Toarcian to Bajocian of Europe), and Ornatoscyllium (Bathonian of England)(Underwood and Ward, 2004; Thies 1983; Kriwet 2003; Kriwet and Klug 2004; Cappetta, 2012). Of these, only Palaeobrachaelurus has been assigned to a family (the Brachaeluridae); the remainder are currently incertae familiae. Of these, only Annea and Ornatoscyllium show any form of ornamentation on the labial face of the crown. In contrast to the condition in Akaimia, a vertical ridge descends the labial face of the central cusp in Annea carinata Thies (1983), originating at the cusp apex and bifurcating basally at a point around a third of the way down the cusp midline. In Ornatoscyllium freemani Underwood and Ward (2004), a somewhat curved vertical ridge extends for the greater part of the length of the central cusp midline, terminating before the cusp apex and just above the labial margin of the labial apron (Underwood and Ward 2008, pl. 8 figs $1,6,8)$. Short vertical ridges may be present at the bases of the lateral cusplets (Underwood and Ward, 2008, pl. 8 figs. 8, 11), especially in lateral teeth. The moderate labial apron has a more squared outline than is the case in teeth of Akaimia. It is quite possible that Akaimia, Ornatoscyllium and Annea will subsequently be shown to belong together in the same family of orectolobiform sharks.

When Rees (2010) originally erected the genus Akaimia he identified six distinguishing characters. As at that time Akaimia was considered monotypic, his diagnosis for the species was the same as that for the genus. However, the discovery of a species of Akaimia distinct from A. altucuspis requires minor modification to the generic diagnosis (see above). Our revised diagnosis for the type species $A$. altucuspis is as follows: 1 , short cusplets that diverge laterally from the main cusp; 2 , only one pair of cusplets in both anterior and lateral teeth; 3, a well-defined labial apron in anterior and lateral teeth.

A damaged tooth described by Thies (1989, fig. 12, referred to Orectolobiformes inc. fam., gen. et sp.) from the Callovian (Jason-zone) of the abandoned Hansa iron mine in Halingerode, Germany, is here referred to A. altucuspis based on the ridge on the labial surface and diverging, single pair of 
lateral cusplets. The labial apron of this tooth is broken, but what remains suggests an apron more

similar to those of A. altucuspis than A. myriacuspis.

The Oxford Clay has yielded a diverse range of elasmobranch taxa, whose discovery dates back to the early years of Oxford Clay palaeontology (Woodward 1889). Elasmobranch taxa are known from skeletal material, such as the archetypal Jurassic shark taxon Hybodus (Martill 1991) although the majority of taxa, including Akaimia myriacuspis sp. nov., are known from microfossils. Of particular interest here is the diversity of orectolobiform sharks, comprising the genera Palaeobrachaelurus, Ornatoscyllium and now Akaimia.

Today, the Orectolobiformes comprises 44 species belonging to 13 genera in 7 families of at least 519 known extant species belonging to 107 genera in 34 families (Compagno et al., 2005). The Orectolobiformes present a range of sizes and modes of life, from animals such as the largest living fish- the open-ocean filter feeding Whale Shark, Rhincodon, to bottom feeders such as the Wobbegong (Orectolobidae) and Nurse Shark (Ginglymostomatidae).

\section{TABLE 1 HERE}

Orectolobiformes comprise almost half of the known shark taxa in the Oxford Clay - 4 of 11 species reported (3 of 10 genera) (Table 1). A similar proportion is also seen in the CallovianOxfordian of Poland (Rees 2010), from where the type species of Akaimia was described. These comprise 5 of the 12 species ( 4 of the 9 genera). The Callovian-aged formation from which we refer the tooth found by Thies (1989) is not mentioned and so we cannot compare the taxa known from the formation, however we can instead look at the taxa described in Germany as a whole (as well as England and Poland) during the Callovian and Oxfordian, although only one orectolobiform is known from this period in Germany.

Comparing the taxa themselves however, a number overlap between the Callovian-Oxfordian of Germany, Poland and England. Sphenodus longidens has been found in all three countries, with 12 taxa being found in at least two of the countries, four of which are common to at least two of the localities. Clearly, the epeiric seas of the northwest European platform contained a broadly cosmopolitan selachian assemblage. 


\section{Acknowledgements}

We thank Hanson UK for allowing us access to the Must Farm clay pit, Mr Andrew Mortlock for his help in the field, Detlev Thies (Hannover), Charlie Underwood (London) and David Ward (Orpington) for their valuable comments on elasmobranch tooth identification, Elaine Dyer for her assistance with scanning electron microscopy and Emma Bernard (NHMUK) for curation advice.

\section{References}

Andrews, C.W. 1910-1913. A descriptive catalogue of the marine reptiles of the Oxford Clay. Vol. 1, 205 pp., 10 pls. (1910); Vol. 2, 206 pp., 13 pls. (1913). British Museum (Natural History), London.

Applegate, S.P., 1972. A revision of the higher taxa of orectolobids. Journal of the Marine Biological Association of India 14, 743-751.

Araujo, R., Smith, A.S., Liston, J., 2008. The Alfred Leeds fossil vertebrate collection of the National Museum of Ireland-Natural History. Irish Journal of Earth Sciences 26, 17-32.

Benton, M.J., Spencer, P.S., 1995. Fossil Reptiles of Great Britain. Chapman \& Hall, London, 386 pp. Bonaparte, C.L.J.L., 1838. Selachorum tabula analytica. Nuovi Annali delle Scienze Naturali 1, 195214.

Brito, P.M., Ferreira, P.L.N., 1989. The first hybodont shark, Tribodus limae n.g., n.sp., from the Lower Cretaceous of Chapada do Araripe (North-East Brazil). Anais da Academia Brasileira de Ciencias 61, 53-57.

Brown, D.S., 1981. The English Upper Jurassic Plesiosauroidea (Reptilia) and a review of the phylogeny and classification of the Plesiosauria. Bulletin of the British Museum (Natural History), Geology Series 35, 253-347.

Cappetta, H., 2012. Chondrichthyes. Mesozoic and Cenozoic Elasmobranchii: Teeth. In: Schultze, H.-P. (Ed.), Handbook of Paleoichthyology Verlag Dr Friedrich Pfeil, München, pp. 1-512. 
Carvalho, M.R., Kriwet, J., Thies, D., 2008. A systematic and anatomical revision of Late Jurassic angelsharks (Chondrichthyes: Squatinidae). In: Arratia, G., Schultze, H.-P., Wilson, M.V.H. (Eds.), Mesozoic Fishes 4 - Homology and Phylogeny. Verlag Dr. Friedrich Pfeil, München, Germany, 469-502.

Compagno, L.J.V., 1977. Phyletic relationships of living sharks and rays. American Zoologist 17, 303-322.

Compagno, L.J.V., Dando, M., Fowler, S., (Eds.), 2005. Sharks of the World. Princeton and Oxford, Princeton University Press, Princeton Field Guides. 368pp.

Ginter, M., Hampe, O., Duffin, C.J. 2010. Handbook of Paleoichthyology. Volume 3D.

Chondrichthyes. Paleozoic Elasmobranchii: Teeth. Verlag Dr Friedrich Pfeil, München, 168 pp. Hallam, A. 2001. A review of the broad pattern of Jurassic sea-level changes and their possible causes in the light of current knowledge. Palaeogeography, Palaeoclimatology, Palaeoecology 167, 2337.

Hay, O.P. 1902. Bibliography and catalogue of the fossil vertebrata of North America. Bulletin of the United States Geological Survey 179, 1-868

Hudson, J.D., Martill, D.M. 1991. Introduction. In: Martill, D.M., Hudson, J.D. (Eds.), Fossils of the Oxford Clay. Palaeontological Association, London, Field Guide to Fossils 4, 11-34.

Hudson, J.D., Martill, D.M., 1994. The Peterborough Member (Callovian, Middle Jurassic) of the Oxford Clay Formation at Peterborough, UK. Journal of the Geological Society of London 151, 113-124.

Johanson, Z., Smith, M.M. 2003. Placoderm fishes, pharyngeal denticles, and the vertebrate dentition. Journal of Morphology 257, 289-307.

Klug, S., Kriwet, J., 2013. Node age estimations and the origin of angel sharks, Squatiniformes (Neoselachii, Squalomorphii). Journal of Systematic Palaeontology 11, 91-110.

Kriwet, J. 2003. Neoselachian remains (Chondrichthyes, Elasmobranchii) from the Middle Jurassic of SW Germany and NW Poland. Acta Palaeontologica Polonica 48, 583594. 
Kriwet, J., Klein, S., 2004. Late Jurassic selachians (Chondrichthyes, Elasmobranchii) from southern Germany: re-evaluation on taxonomy and diversity. Zitteliana, 67-95.

Leeds, E.T., 1956. The Leeds collection of fossil reptiles from the Oxford Clay of Peterborough. Blackwell, Oxford,104 pp.

Liston, J., 2008. A review of the characters of the edentulous pachycormiforms Leedsichthys, Asthenocormus and Martillichthys nov. gen. In: Arratia, G., Schultze, H.-P., Wilson, M. V. H. (Eds.), Mesozoic Fishes 4 Homology and Phylogeny, 181-198.

Martill, D.M., Hudson, J.D. (Eds.), 1991. Fossils of the Oxford Clay. London, Palaeontological Association. Field Guides to Fossils Series No. 4, 286 pp.

Martill, D.M. 1991. Fish. In: Martill, D.M., Hudson, J.D. (Eds.), Fossils of the Oxford Clay. Palaeontological Association, London, Field Guide to Fossils 4, 197-225.

Metcalf, S.J., Vaughan, R.F., Benton, M.J., Cole, J., Simms, M.J., Dartnall, D.L., 1992. A new Bathonian (Middle Jurassic) microvertebrate site within the Chipping Norton Limestone Formation at Hornsleasow Quarry, Gloucestershire. Proceedings of the Geologists' Association $103,321-342$.

Metcalf, S.J., Walker, R.J., 1993. A new Bathonian microvertebrate locality in the English Midlands. In: Fraser, N.C., Sues , H.-D. (Eds.), In the Shadow of the Dinosaurs: Early Mesozoic Tetrapods. Columbia University Press, New York. 322-331.

Mettam, C., Johnson, A.L.A., Nunn, E.V., Schöne, B.R., 2014. Stable isotope $\left(\delta^{18} \mathrm{O}\right.$ and $\left.\delta^{13} \mathrm{C}\right)$ sclerochronology of Callovian (Middle Jurassic) bivalves (Gryphaea (Bilobissa) dilobotes) and belemnites (Cylindroteuthis puzosiana) from the Peterborough Member of the Oxford Clay Formation (Cambridgeshire, England): Evidence of palaeoclimate, water depth and belemnite behaviour. Palaeogeography, Palaeoclimatology, Palaeoecology 399, 187-201.

Rees, J., 2005. Neoselachian shark and ray teeth from the Valanginian, Lower Cretaceous, of Wąwał, Central Poland. Palaeontology 48, 209-221.

Rees, J. 2010. Neoselachian sharks from the Callovian-Oxfordian (Jurassic) of Ogrodzieniec, Zawiercie region, southern Poland. Palaeontology 53, 887-902. 
Rees, J., Underwood, C.J., 2008. Hybodont sharks of the English Bathonian and Callovian (Middle Jurassic). Palaeontology 51, 117-147.

Roux, W., 1887. Uber eine im Knochen lebende Gruppe von Fadenpilzen (Mycelites ossifragus). Zietschrift für wissenschaftliche. Zoologie 45, 227-254.

Shirai, S. 1996. Phylogenetic interrelationships of neoselachians. In: Stiassey, M.L.J., Parenti, L.R., Johnson, G.D. (Eds.), Interrelationships of fishes. Academic Press, San Diego, 9-34.

Thies, D., 1983. Jurazeitliche Neoselachier aus Deutschland und S-England. Courier Forschungsinstitut Senckenberg 58, 1-117.

Thies, D., 1989. Some problematical sharks teeth (Chondrichthyes, Neoselachii) from the Early and Middle Jurassic of Germany. Paläontologische Zeitschrift 63, 103-117.

Thies, D., Leidner, A., 2011. Sharks and guitarfishes (Elasmobranchii) from the Late Jurassic of Europe. Palaeodiversity 4, 63-184.

Underwood, C. J., 2002. Sharks, rays and a chimaeroid from the Kimmeridgian (Late Jurassic) of Ringstead, southern England. Palaeontology 45, 297-325.

Underwood, C. J., Mitchell, S. F., Veltkamp, C. J., 1999. Microborings in mid-Cretaceous fish teeth. Proceedings of the Yorkshire Geological Society 52, 269-274.

Underwood, C.J., Ward, D.J., 2004. Neoselachian sharks and rays from the British Bathonian (Middle Jurassic). Palaeontology 47, 447-501.

Woodward, A.S. 1889. Catalogue of the fossil fishes in the British Museum (Natural History). Part I. Elasmobranchii. Taylor and Francis, London, 474 pp.

Woodward, A.S. 1890. Note on the gill-rakers of Leedsia problematica - a gigantic fish from the Oxford Clay. Geological Magazine December III (7), 292-293. 


\section{FIGURE CAPTIONS}

Fig. 1. Map showing location of Must Farm clay pit, near Whittlesey, Cambridgeshire. Currently this is the only working clay pit excavating the Peterborough Member of the Oxford Clay Formation.

Fig. 2. Simplified stratigraphic log for the Peterborough Member of the Oxford Clay Formation at Whittlesey, Cambridgeshire. Based on Martill and Hudson (1994).

Fig. 3. Diagram to show the key descriptive terms used in the text. Akaimia myriacuspis anterior tooth in (a) labial view and (b) oblique distal view. Lateral tooth of Akaimia myriacuspis in (c) labial view, and (d) lateral view.

Fig. 4. Indet. denticle showing Mycelites ossifragus boring networks on the 'lingual' surface NHMUK PV P 73695. Orientation terms follow dental criteria. a, lingual view; b, labial view; c, lateral view; d, oblique view. Scale bar $=1 \mathrm{~mm}$.

Fig. 5. Five examples of Akaimia myriacuspis sp. nov. a-e, holotype specimen NHMUK PV P 73690 in a, occlusal, b, labial, c, lingual, d, left lateral and e, right lateral views. f-h, paratype NHMUK PV P 73691 in f, labial, g, left lateral and h, right lateral views. i-k paratype NHMUK PV P 73692 in i, slightly oblique labial view, $\mathrm{j}$, occlusal and $\mathrm{k}$, right lateral views. 1-o, lateral tooth paratype NHMUK PV P 73693 in 1, labial, m, lingual, n, left lateral and o, right lateral views. p-q, additional specimen missing distal crown NHMUK PV P 73694 in p, labial and q, right lateral views. Scale bar $=1 \mathrm{~mm}$.

Table 1. Distribution of elasmobranch taxa in the Callovian-Oxfordian of NW Europe. Based on data in Kriwet (2003), Kriwet and Klein (2004), Metcalf et al., (1992), Metcalf and Walker (1993), Rees (2005), Thies (1983), Underwood (2002), Underwood and Ward (2004). 


\begin{tabular}{|c|c|c|c|c|c|c|c|c|}
\hline \multicolumn{3}{|c|}{ Systematics } & \multicolumn{3}{|c|}{ Country } & \multicolumn{3}{|c|}{ Locality } \\
\hline Order & Family & Taxon & Germany & Poland & England & $\begin{array}{c}\text { Hansa } \\
\text { iron mine }\end{array}$ & $\begin{array}{c}\text { Ogrodzieniec } \\
\text { Quarry }\end{array}$ & $\begin{array}{c}\text { Oxford } \\
\text { Clay }\end{array}$ \\
\hline Hybodontiformes & Hybodontidae & $\begin{array}{l}\text { Hybodus obtusus } \\
\text { H. dawni } \\
\text { Asteracanthus ornatissimus } \\
\text { A. acutus } \\
\text { A. medius } \\
\text { Planohybodus peterboroughensis } \\
\text { Lissodus leiodus }\end{array}$ & $\begin{array}{l}x \\
x \\
x\end{array}$ & & $\begin{array}{l}\times \\
\times \\
\times \\
\times \\
\times \\
\times \\
\times\end{array}$ & & & $x$ \\
\hline Heterodontiformes & Heterodontidae & $\begin{array}{l}\text { Paracestracion falcifer } \\
\text { P. sarstedenesis } \\
\text { P. sp. } \\
\text { Heterodontus duffini }\end{array}$ & $x$ & & $\begin{array}{l}x \\
\times \\
\times \\
\times\end{array}$ & & & $\begin{array}{r}x \\
\times \\
\end{array}$ \\
\hline Orectolobiformes & $\begin{array}{l}\text { Indet. } \\
\text { Indet. } \\
\text { Indet. } \\
\text { Hemiscyllidae }\end{array}$ & $\begin{array}{l}\text { Ornatoscyllium pattersoni } \\
\text { O. sp. } \\
\text { Akaimia myriacuspis sp. nov. } \\
\text { A. altuscuspis } \\
\text { Palaeobrachaelurus bedfordensis } \\
\text { Pb. alisonae } \\
\text { Pb. sp. } \\
\text { Pseudospinax sp. } 1 \\
\text { Psp sp. } 2\end{array}$ & $\times$ & $\begin{array}{l}\times \\
\times \\
\times \\
\times \\
\times \\
\end{array}$ & $\begin{array}{l}x \\
\times \\
x \\
x\end{array}$ & $x$ & $\begin{array}{l}\times \\
\times \\
\times \\
\times \\
\times\end{array}$ & $\begin{array}{l}x \\
\times \\
x \\
x\end{array}$ \\
\hline Synechodontiformes & $\begin{array}{l}\text { Palaeospinaciidae } \\
\text { Orthacodontidae } \\
\text { Pseudonotidanidae }\end{array}$ & $\begin{array}{l}\text { Paraorthacodus sp. } \\
\text { Synechodus riegrafi } \\
\text { Syn. sp. } \\
\text { 'Synechodus' prorogatus } \\
\text { Sphenodus macer } \\
\text { Sph. longidens } \\
\text { Sph. nitidus } \\
\text { Sph. sp. } \\
\text { Welcommia cappetti }\end{array}$ & $\begin{array}{l}\times \\
\times \\
\times \\
\times \\
\times \\
\times\end{array}$ & $\begin{array}{l}\times \\
\times \\
\times \\
\times \\
\times\end{array}$ & $x$ & & $\begin{array}{l}x \\
\times \\
x \\
\times \\
x\end{array}$ & $x$ \\
\hline Hexanchiformes & & "Eonotidanus" serratus & & & $x$ & & & \\
\hline
\end{tabular}




\begin{tabular}{|c|c|c|c|c|c|c|c|}
\hline & Hexanchidae & $\begin{array}{l}\text { Notidanus muensteri } \\
\text { Notidanoides muensteri } \\
\text { Notidanoides sp. } \\
\text { Hexanchidae indet. }\end{array}$ & $\begin{array}{l}x \\
x\end{array}$ & $\begin{array}{l}x \\
\times \\
\end{array}$ & $x$ & $\begin{array}{l}x \\
x \\
\end{array}$ & $x$ \\
\hline Squaliformes & Squalidae & Squalogaleus $\mathrm{sp}$. & & $x$ & & & \\
\hline Protospinaciformes & Protospinacidae & $\begin{array}{l}\text { Protospinax annectans } \\
\text { Prot. lochensteinensis } \\
\text { Prot. muftius } \\
\text { Prot. sp. } 1 \\
\text { Prot. sp. } 2\end{array}$ & $\begin{array}{l}x \\
x\end{array}$ & & $x$ & & \\
\hline Squatiniformes & Squatinidae & $\begin{array}{l}\text { Pseudorhina cf. alifera } \\
\text { Pseu. sp. }\end{array}$ & $\begin{array}{l}x \\
x \\
\end{array}$ & & $x$ & & $x$ \\
\hline Rajiformes & Rhinobatidae & Spathobatis werneri & & & $x$ & & $x$ \\
\hline
\end{tabular}




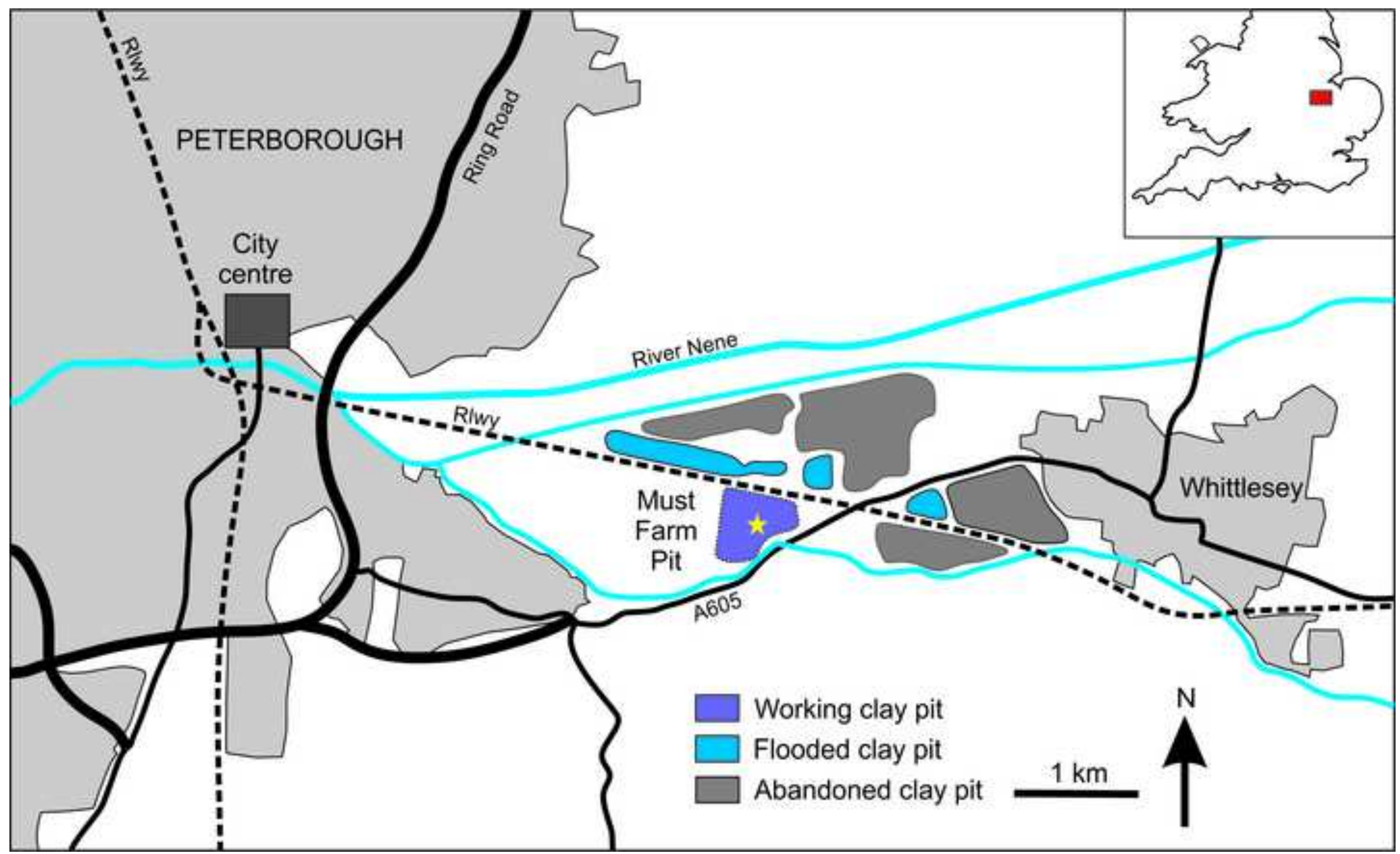




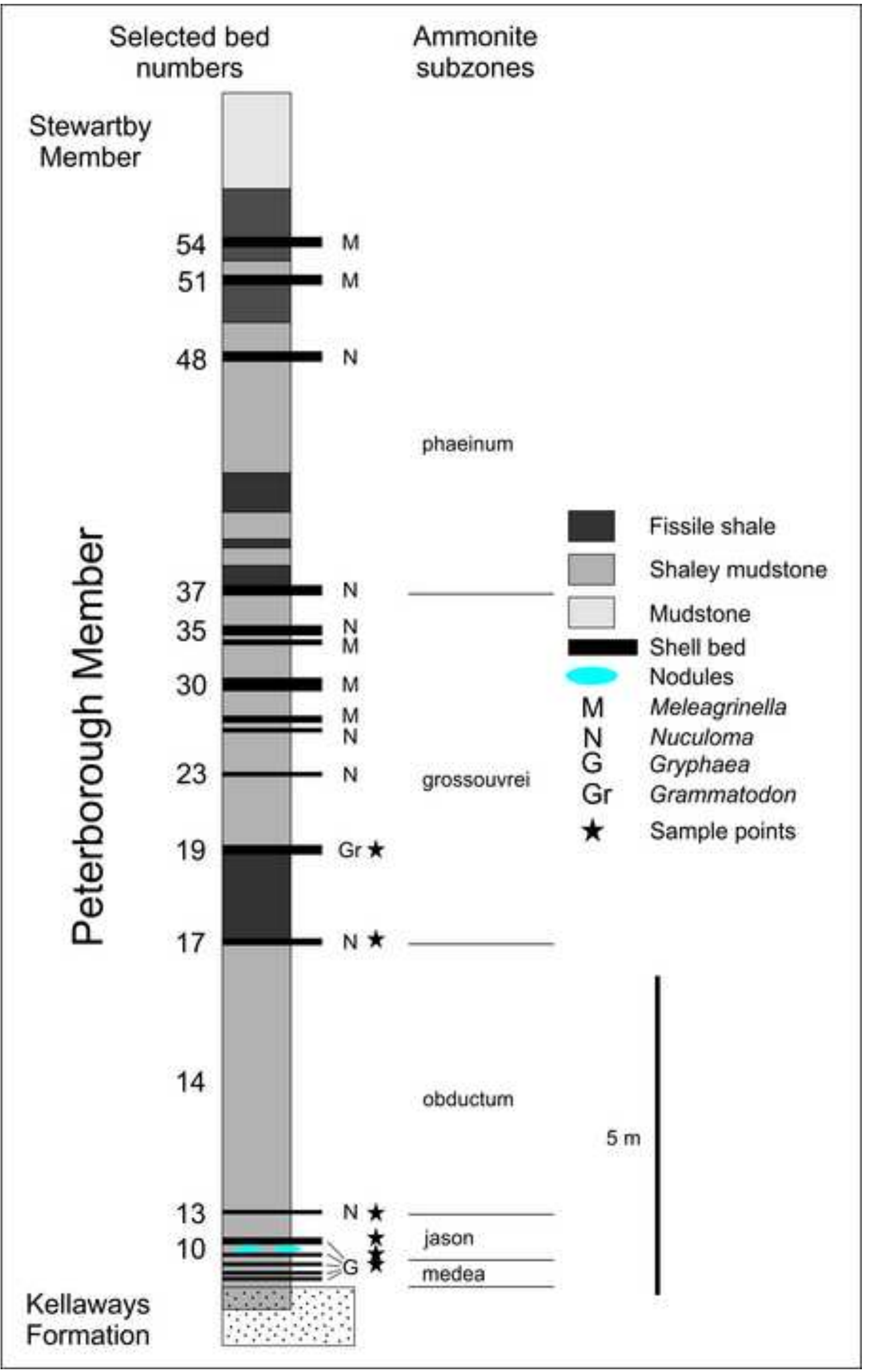



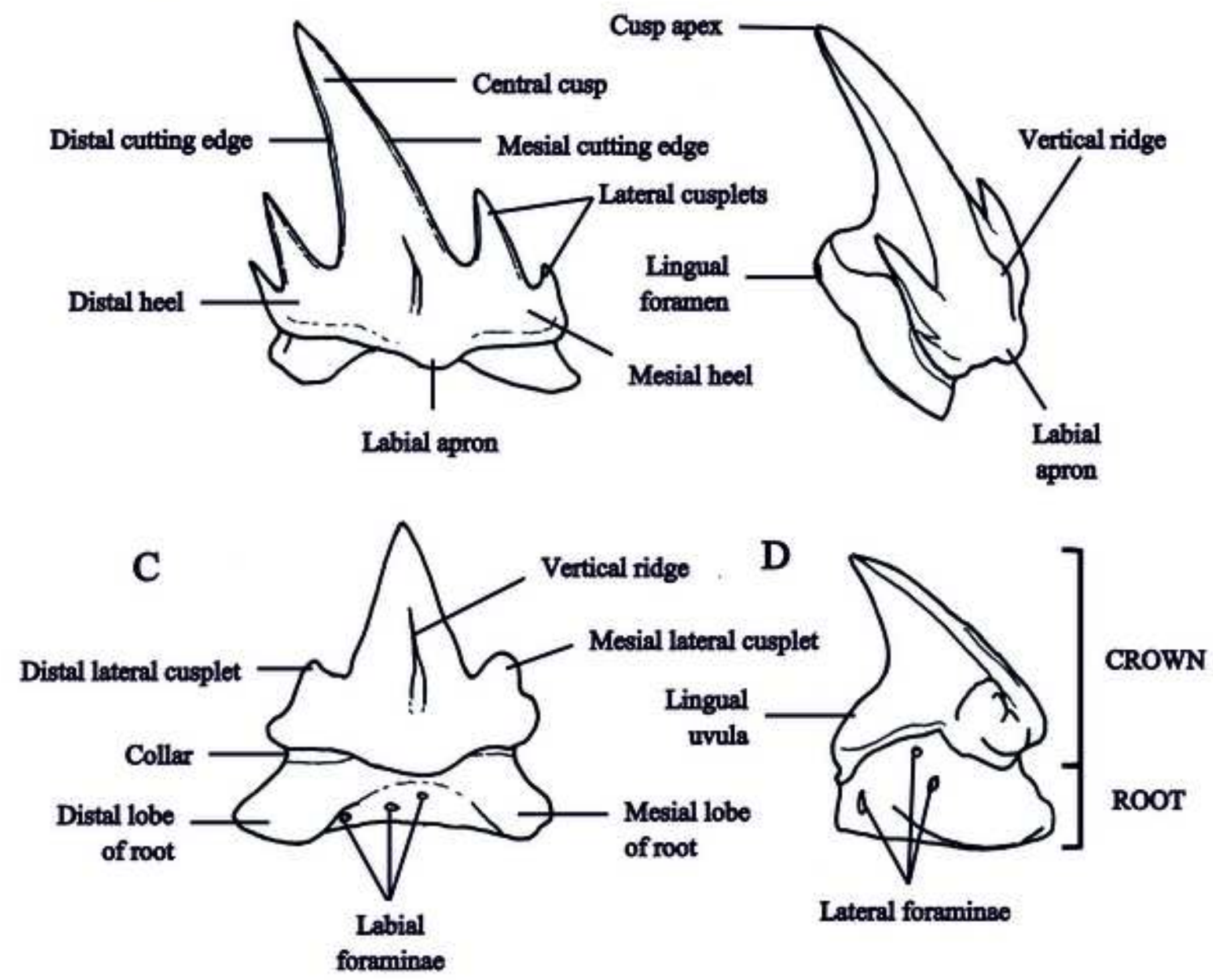



b

d

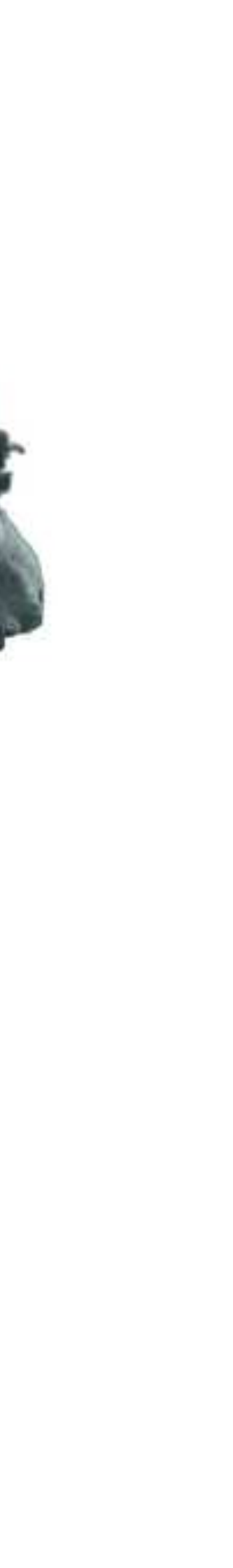

Figure 4
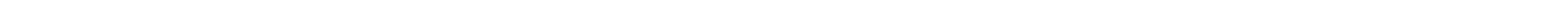

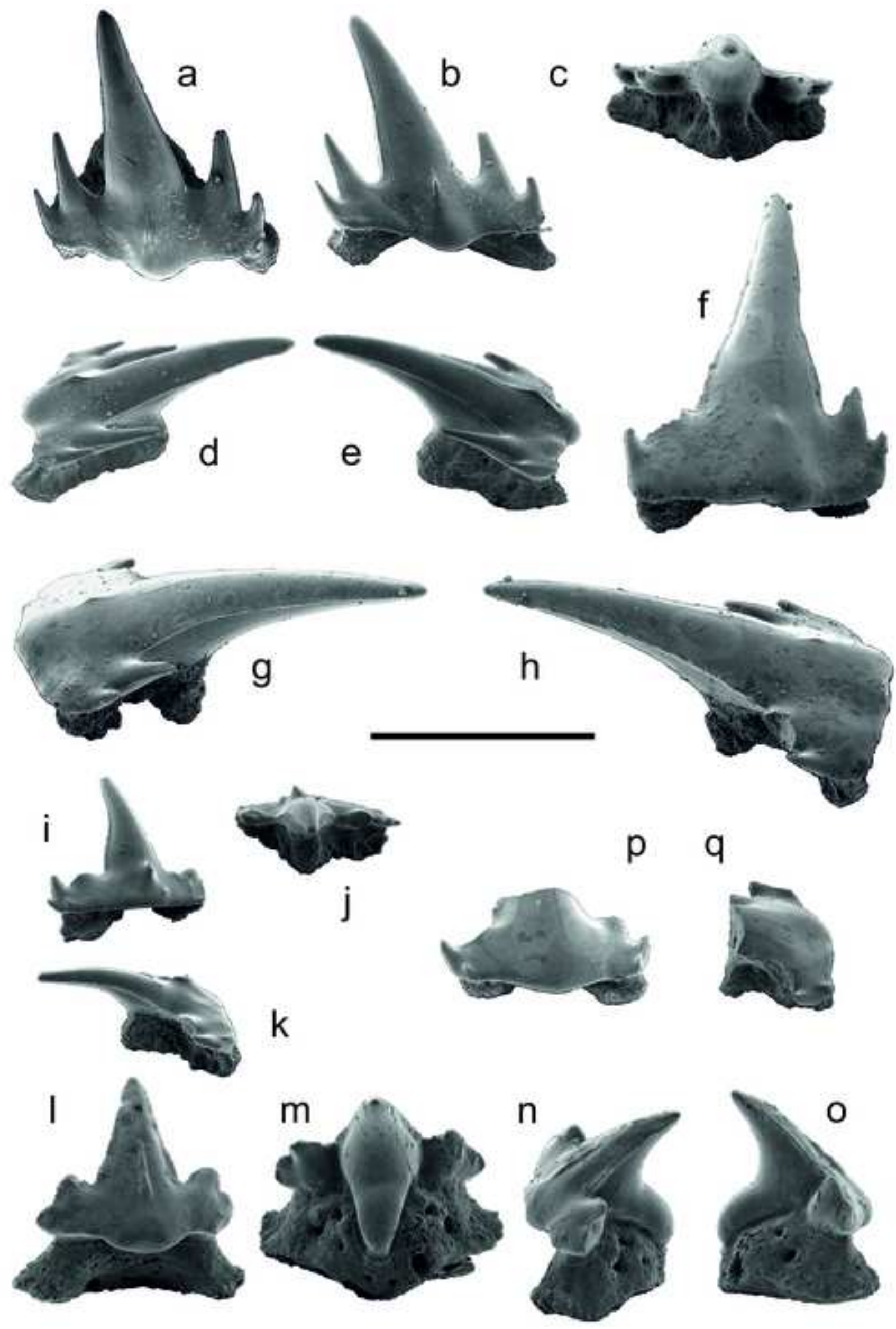